\title{
Design and Analysis of Water Distribution Network Using EPANET and GIS for Pattanam Rural Area of Coimbatore District
}

\author{
Aathira $\mathrm{M}^{1}$ and Elangovan $\mathrm{K}^{2}$ \\ \{aathiramanikandan@gmail.com ${ }^{1}$, ela.civil@psgtech.ac.in ${ }^{2}$ \} \\ ${ }^{1}$ Former Post Graduate Student, M.E. Infrastructure Engineering, ${ }^{2}$ Professor, Department of Civil \\ Engineering,PSG College of Technology, Coimbatore 641004
}

\begin{abstract}
Water distribution analysis and design is one of the challenging aspects in civil engineering which involves looping system of water distribution with extreme level of bursting pressure like lower than the atmosphere or much heavier pressure beyond the surge level due to differential elevations. The two major constraints that directly involved in major distributions are effective diameter of the pipe and permissible level of pressure at each nodal links/demand points. The paper deals with the planning of water distribution network through combined gravity and pumping looping system of network and satisfies the overall demand at each nodal point in and around the study area. The study area chosen is Pattanam rural area of Coimbatore district, Tamil Nadu. The population of the study area is 10,020 . The present scenario in the study area is the presence of 9 overhead water tanks with average capacity of 40,000 litres. The feasibility of integrating the main supply with a single tank for the study area is checked. With the data obtained from field survey and data collection, a spatially bound model is created using ArcView GIS software. The output of ArcView model is then interchanged to EPANET input file with the help of interchange tool. This model is then imported in EPANET software. Keeping the flow and demand as a major factor and optimum diameter and pressure as constraints, a network is generated in EPANET software package. The output model from EPANET is checked for accuracy with manual calculation that is carried out using Hazen-William's chart as well as with the field scenario. An integrated water distribution network model is thus suggested for the study area. The various tanks in the study area account for more head loss as well as more maintenance as many of the tanks are located to serve undeserved areas. Thus, a new tank location is identified foreseeing the further population expansion of the study area. The existing pipe line is maintained the same to the maximum extent except for some increase in diameter of pipes in the main line. The further scope of the project is the model creation and spatial analysis using GIS and water distribution system modelling packages integrating with GPS for more simplified and cost effective surveying, modeling as well as maintenance of the water distribution network system.
\end{abstract}

Keywords: Water Distribution, Head loss, ArcView GIS, GPS, EPANET, Hazen William's Chart, integrate, new tank location.

\section{Introduction}

\subsection{Water Distribution Network}

Water distribution network analysis is important to supply water to all the service areas without interruption. GIS is highly useful to capture the spatial aspects of the water distribution network. It consists of valves, pipes and related components. GIS shall be integrated with EPANET software for effective analysis

\subsection{Scope}

The present scope of the project is to develop a "Water Distribution Network" (WDN) for Pattanam rural area of Coimbatore District" by keeping major constraints as optimum diameter and pressure at each node of the distribution network. A new WDN is to be proposed based on the gravity flow which will be controlled through elevated water tanks along with distribution system to all demand zones in and around the study area (PATTANAM rural area) with average consumable by the individual users.

This paper finds its scope as

Increase in need to replace the traditional methods with accurate, speedy and computer based software.

GIS is highly effective in analysing water distribution network alongwith EPANET software. It is easy to update and carry out the analysis in a computerised environment. 


\subsection{Objective}

- To Collect the data (plan layout, topographical study) pertaining to the water distribution network model development

- To arrive an optimum network model and evaluate the major two constrains (Effective Diameter and Permissible Pressure)

- To assess the performance of the drinking water distribution system network in Pattanam rural area.

- To address any improvements required to the existing Water Distribution Network.

\section{Study Area}

Pattanam is a village in Sulur Taluk in Coimbatore District of Tamil Nadu. It is located 9Kms towards East from District Head Quarters Coimbatore and $13 \mathrm{Km}$ from Sulur. The study area is along the border of the Coimbatore District and Tiruppur District. Panchayat headquarters for Pattanam village is at Pattanam.

Pattanam village has a population of 10020 with area of 11.85 square kilometers with 12 wards. The present water distribution network consists of 22 bore-wells, 8 open wells, 2-handpumps, 9 overhead tanks and 8 ground level reservoirs. The main source of water supply to the study area is from Athikadavu and in minor scale from Noyyalriver.

The 9 tanks located in the study area are identified to serve most of undeserved area and the tanks are located at closer to each other. The existing tanks serves some of the deserved areas, the head loss and maintenance involved in these tanks can be overcome by replacing a single tank over these 9 tanks. Figure 1 shows the digitized boundary of Pattanam Village.

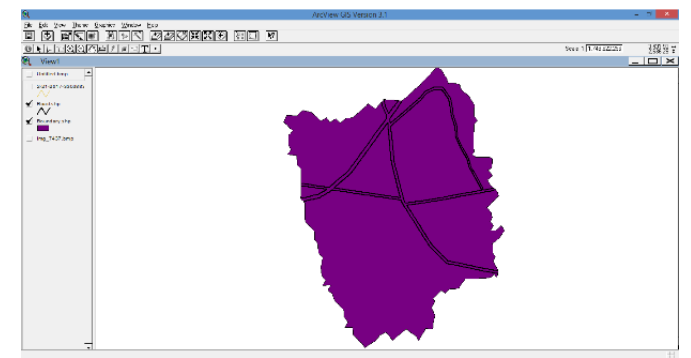

Figure 1: Digitized Pattanam village boundary

\section{ArcView}

\subsection{GIS application for water distribution systems}

GIS is useful to carry out hydraulic modeling, skeletonisation of water distribution network model, synchronize the model with EPANET, Run he model and read the output of the model

\subsection{ArcView}

The elevation, latitude and longitude details were given as input data in ArcView. These details were collected using GPS in the field. Based on these details a network was created with respect to the existing network in the area.

The steps followed to create a network model are as follows:

Step 1: Water Distribution model creation using polyline theme. Refer figure 2

Step 2: Geo-referencing Network model created. Refer figure 3. 


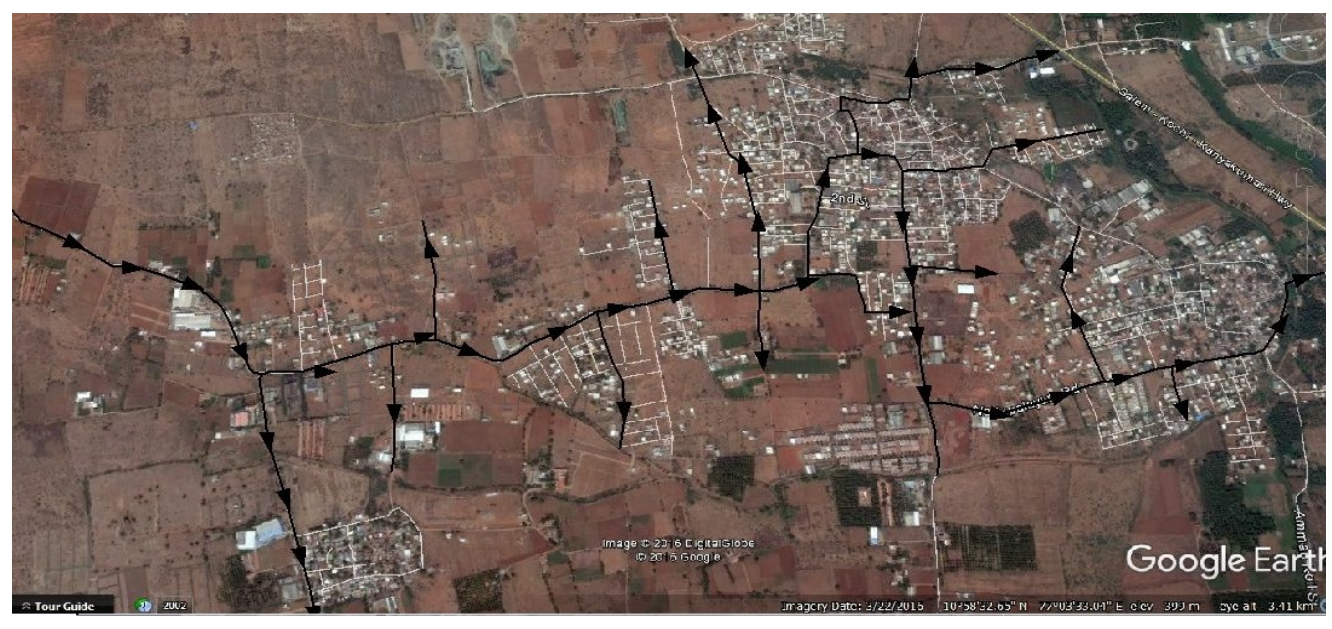

Figure 2: Network model creation using ArcView

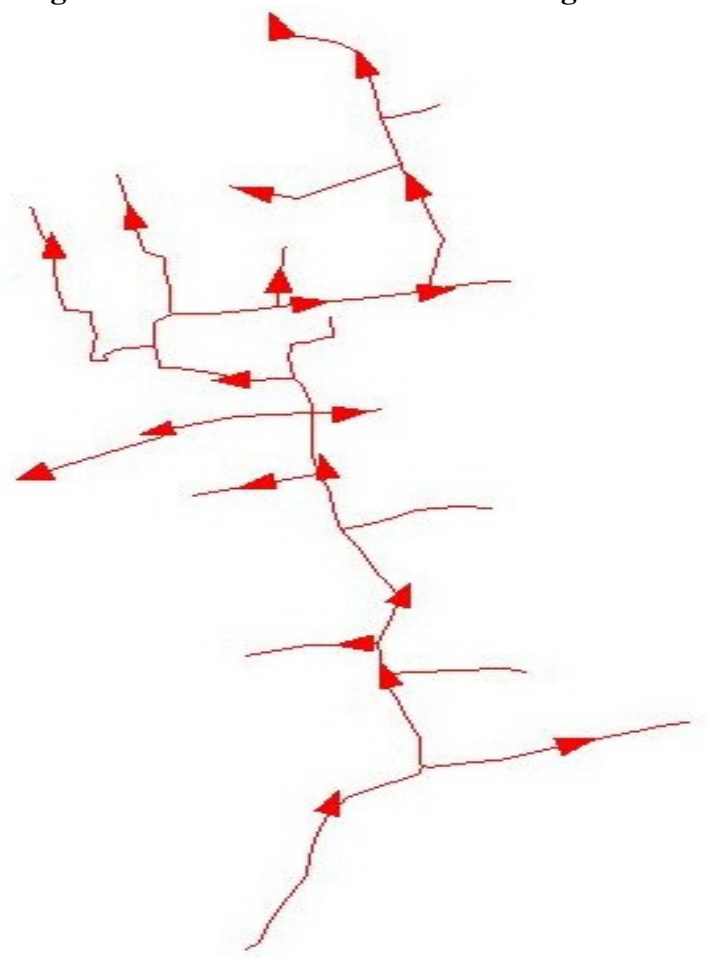


Figure 3: Geo-referenced Network model

\section{ArcView TO EPANET Interchange}

EPANET provides the capability for input, run he model and create simulations. One shall create the water distribution model in ArcView and the model shall be exported to EPANET $^{[12]}$

\section{EPANET}

EPANET was developed by US Environmental Agency. The model consist of pipes, pumps, valves, nodes, reservoirs and tanks. It is possible to find the concentration of water in pipes, water age, source tracing, velocity of water.

In this paper, the work of model creation in EPANET has been simplified with the help of ArcView software. The output file after interchange is directly loaded in EPANET software

After importing file from ArcView assign the demand, elevation and diameter details and run the network for analysis. Figure 4 shows the EPANET output model with flow and demand details. 


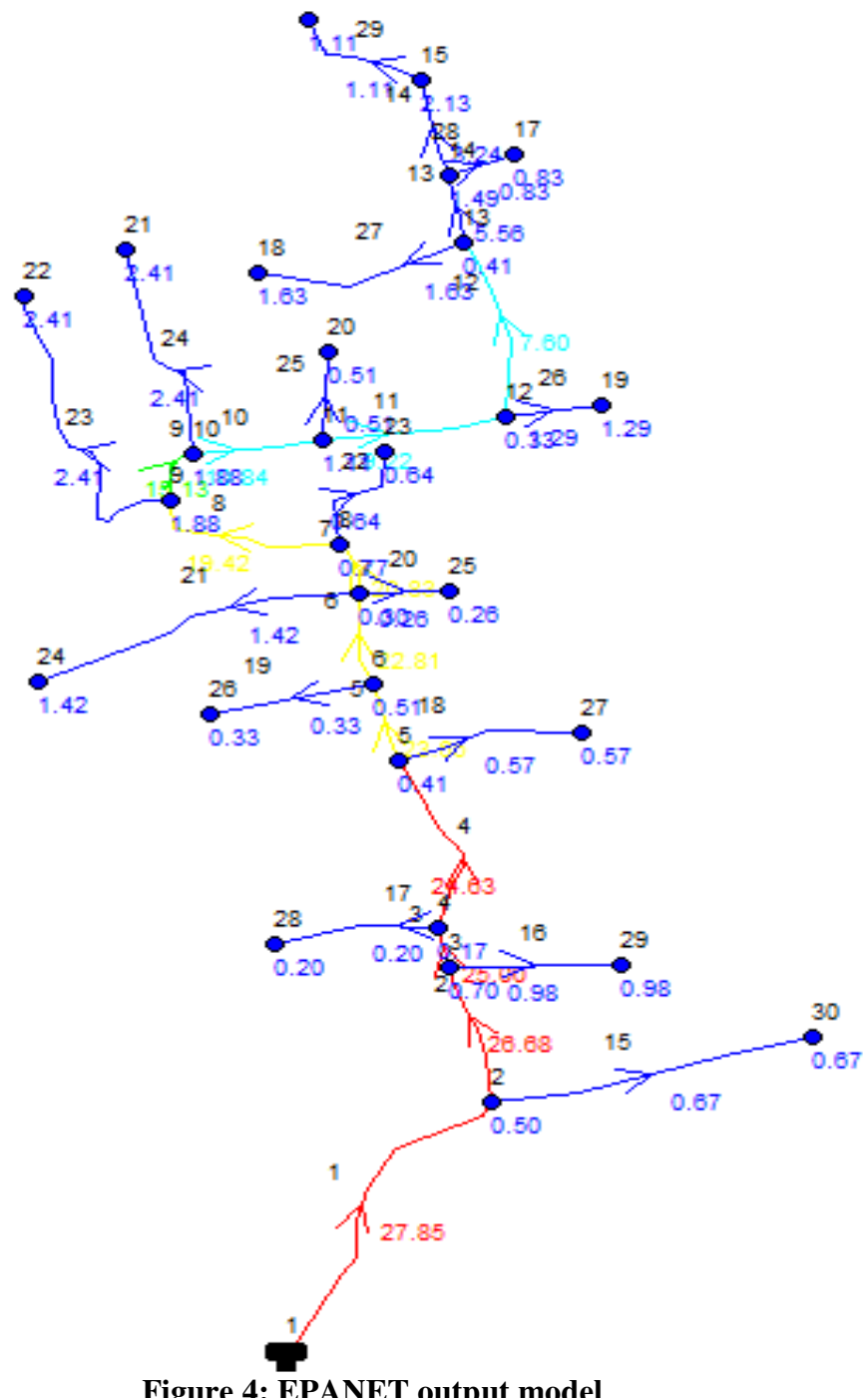

Figure 4: EPANET output model

\section{Manual calculations}

Depending upon various factors such as relative levels of the different zones of the city, the layout of the roads etc., the type of distribution network is to be adopted. Considering the irregularity in expansion of the study area and the absence of planned full-fledged road network, dead end system is adopted.

The main object of distribution system is to develop adequate water pressure at various points of the consumer's taps. Depending upon the level of the source of water, 
topography of the area water may be forced into the distribution system by gravitational, pumping or combined systems. The system adopted in this case is combined gravity and pumping system in which water is pumped from the source to the over-head tank using pumping system and then from the over-head tank to the consumers by the mere action of gravity.

Even though the distribution system in Indian cities take maximum pressure head of hardly $8-15 \mathrm{~m}^{[11]}$, Clause 4.13 .1 of SP:35(S\&T)-1987 ${ }^{[13]}$ suggests pressure head between $3 \mathrm{~m}$ and $10 \mathrm{~m}$ for domestic meters. The study area mostly comprises of single storey building the minimum head adopted is $6 \mathrm{~m}$. Since the design of pipe diameter involves various trial, HazenWilliam's Chart is used in the design of pipe diameters. ${ }^{[11]}$

Table 1 shows the manual calculation carried out using Hazen-Williams chart.

Table 1 Manual calculation

\begin{tabular}{|c|c|c|c|c|c|c|c|c|c|c|c|}
\hline \multicolumn{3}{|c|}{$\begin{array}{l}\text { Material used: CI } \\
\text { pipes } \\
\text { Hazen's Williams } \\
\text { Coefficient-100 }\end{array}$} & \multicolumn{5}{|c|}{$\begin{array}{l}\text { CALCULATION OF PIPE } \\
\text { DIAMETER USING HAZEN's- } \\
\text { WILLIAM's MONOGRAM }\end{array}$} & \multicolumn{4}{|c|}{$\begin{array}{l}\text { Assumed Minimum Head } \\
\text { Loss }=6 \mathrm{~m}\end{array}$} \\
\hline \multirow{2}{*}{ 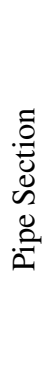 } & \multicolumn{3}{|c|}{ Population served } & \multirow{2}{*}{ 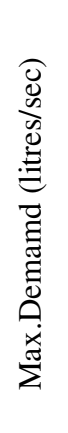 } & \multirow{2}{*}{ 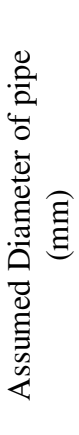 } & \multicolumn{3}{|c|}{ Head Loss } & \multirow{2}{*}{ 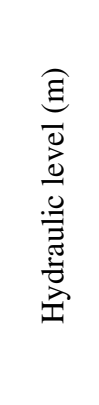 } & \multirow{2}{*}{ 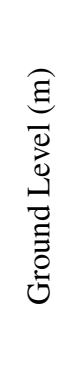 } & \multirow{2}{*}{ 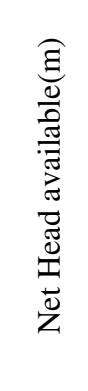 } \\
\hline & 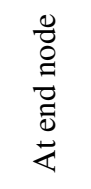 & 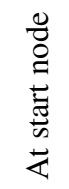 & $\stackrel{\overparen{\pi}}{0}$ & & & 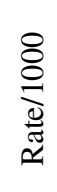 & 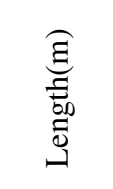 & 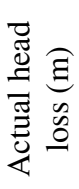 & & & \\
\hline no & 400 & 768 & 1168 & 3.24 & 100 & 3 & 194.06 & $\begin{array}{c}0.5 \\
8\end{array}$ & $\begin{array}{c}396.0 \\
5\end{array}$ & 387 & 9.045 \\
\hline $\mathrm{mn}$ & 1468 & 536 & 2004 & 5.57 & 100 & 8.8 & 184.34 & $\begin{array}{c}1.6 \\
2\end{array}$ & $\begin{array}{c}396.6 \\
3\end{array}$ & 387 & 9.627 \\
\hline $\operatorname{lm}$ & 2592 & 148 & 2740 & 7.61 & 100 & 15 & 490.09 & $\begin{array}{c}7.3 \\
5\end{array}$ & $\begin{array}{c}398.2 \\
5\end{array}$ & 387 & $\begin{array}{c}11.25 \\
0\end{array}$ \\
\hline $\mathrm{kl}$ & 3204 & 120 & 3324 & 9.23 & 150 & 3.7 & 405.78 & $\begin{array}{c}1.5 \\
0\end{array}$ & $\begin{array}{c}405.6 \\
0 \\
\end{array}$ & 391 & $\begin{array}{c}14.60 \\
1 \\
\end{array}$ \\
\hline $\mathrm{jk}$ & 3508 & 400 & 3908 & $\begin{array}{c}10.8 \\
6 \\
\end{array}$ & 150 & 4.6 & 319.18 & $\begin{array}{c}1.4 \\
7\end{array}$ & $\begin{array}{c}407.1 \\
0\end{array}$ & 393 & $\begin{array}{c}14.10 \\
2\end{array}$ \\
\hline $\mathrm{ij}$ & 4776 & 668 & 5444 & $\begin{array}{c}15.1 \\
2 \\
\end{array}$ & 200 & 2.5 & 148.13 & $\begin{array}{c}0.3 \\
7\end{array}$ & $\begin{array}{c}408.5 \\
7\end{array}$ & 394 & $\begin{array}{c}14.57 \\
1\end{array}$ \\
\hline hi & 6312 & 678 & 6990 & $\begin{array}{c}19.4 \\
2\end{array}$ & 200 & 3.7 & 481.07 & $\begin{array}{c}1.7 \\
8\end{array}$ & $\begin{array}{c}408.9 \\
4\end{array}$ & 396 & $\begin{array}{c}12.94 \\
1\end{array}$ \\
\hline gh & 7220 & 276 & 7496 & $\begin{array}{c}20.8 \\
2\end{array}$ & 200 & 4 & 131.73 & $\begin{array}{c}0.5 \\
3\end{array}$ & $\begin{array}{c}410.7 \\
2\end{array}$ & 397 & $\begin{array}{c}13.72 \\
1\end{array}$ \\
\hline
\end{tabular}




\begin{tabular}{|c|c|c|c|c|c|c|c|c|c|c|c|}
\hline fg & 8100 & 108 & 8208 & $\begin{array}{c}22.8 \\
0\end{array}$ & 200 & 4.6 & 242.8 & $\begin{array}{c}1.1 \\
2\end{array}$ & $\begin{array}{c}411.2 \\
5\end{array}$ & 396 & $\begin{array}{c}15.24 \\
8\end{array}$ \\
\hline ef & 8328 & 182 & 8510 & $\begin{array}{c}23.6 \\
4\end{array}$ & 200 & 5 & 210.22 & $\begin{array}{c}1.0 \\
5\end{array}$ & $\begin{array}{c}412.3 \\
6\end{array}$ & 399 & $\begin{array}{c}13.36 \\
5\end{array}$ \\
\hline de & 8716 & 148 & 8864 & $\begin{array}{c}24.6 \\
2\end{array}$ & 300 & 0.7 & 371.37 & $\begin{array}{c}0.2 \\
6\end{array}$ & $\begin{array}{c}413.4 \\
2\end{array}$ & 400 & $\begin{array}{c}13.41 \\
6\end{array}$ \\
\hline cd & 8936 & 60 & 8996 & $\begin{array}{c}24.9 \\
9\end{array}$ & 300 & 0.75 & 117.42 & $\begin{array}{c}0.0 \\
9\end{array}$ & $\begin{array}{c}413.6 \\
8\end{array}$ & 403 & $\begin{array}{c}10.67 \\
6\end{array}$ \\
\hline bc & 9348 & 252 & 9600 & $\begin{array}{c}26.6 \\
7\end{array}$ & 300 & 0.85 & 347.56 & $\begin{array}{c}0.3 \\
0\end{array}$ & $\begin{array}{c}413.7 \\
6\end{array}$ & 404 & 9.764 \\
\hline ab & 9840 & 180 & 10020 & $\begin{array}{c}27.8 \\
3\end{array}$ & 300 & 0.9 & 1045.21 & $\begin{array}{c}0.9 \\
4\end{array}$ & $\begin{array}{c}414.0 \\
6\end{array}$ & 407 & 7.059 \\
\hline
\end{tabular}

\section{Field check}

The result obtained was checked in field with the pressure gauge at two different points in the study area.

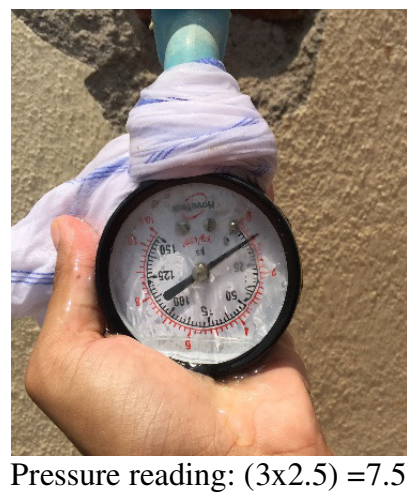

Figure 5: Pressure gauge reading at start node of the street 


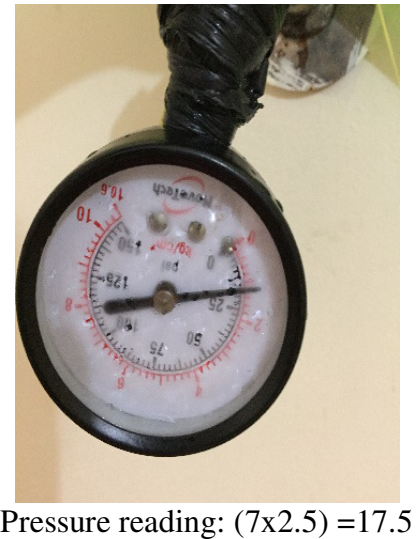

Figure 6: Pressure gauge reading at end node of the street

Table 2 Pressure gauge reading check

\begin{tabular}{|c|c|c|c|}
\hline \multicolumn{4}{|c|}{ PRESSURE CHECK } \\
\hline \begin{tabular}{l}
\multicolumn{2}{c}{ Pressure } \\
at start node \\
of the street
\end{tabular} & $\begin{array}{l}\text { Pressure at } \\
\text { end node of } \\
\text { the street }\end{array}$ & e in $p r$ & $\begin{array}{l}\text { fferenc } \\
\text { ssure }\end{array}$ \\
\hline (psi) & (psi) & psi) & m) \\
\hline 17.5 & 7.5 & $\begin{array}{ll} & 1 \\
0 & \end{array}$ & $03^{7 .}$ \\
\hline
\end{tabular}

\section{Result and Discussions}

The output from EPANET model is taken in graph and table formats and the parameters are checked with the manual as well as field values. It is found that the values are in agreement with each other. But if the results were contradicting then the diameter of the pipes must have varied and the analysis had to be carried out.

\section{Conclusion}

The following inferences are made from analysis:

- ArcView GIS 3.1 provides Geo-referenced network model which can be directly interchanged to EPANET input file.

- This reduces the work of modeling in EPANET and provides more accurate georeferenced data along with the pipe length thus making the input process much easier.

- To assess the prevailing WDN as well as to establish the designing of a new WDN according to the demand and supply prevailing in the study area EPANET was found to be effective and also checks with the accuracy of simulated and existing model. 
- Analysis of demand and drinking water problem with the collection of preliminary data has also been done which clearly shows an additional water supply source to the study area.

- Though the feasibility of increasing the number of tanks and extending the water distribution system is present, taking long term benefit to the society as well as reduction of maintenance cost for various tanks, a single tank supply system is suggested.

- The viability of the project in the chosen study area is also checked with the existing WDN model.

- An integrated water distribution network model is thus suggested for the study area.

- The various tanks in the study area account for more head loss as well as more maintenance as many of the tanks are located to serve undeserved areas.

- Thus, a new tank location is identified foreseeing the further population expansion of the study area.

- The existing pipe line is maintained the same to the maximum extent except for some increase in diameter of pipes in the main line.

\section{Scope for Further Study}

Further suggestions of the betterment of network analysis

- Additional constraints need to be added based on the direct pumping analysis.

- Special provisions for surge tanks and others appurtenances will make better water distribution network.

- Combined effect of chlorine and water age is an addition strength analysis for the arrived water distribution network.

- The further scope of the work is the model creation and spatial analysis using GIS and water distribution system modelling packages integrating with GPS for more simplified and cost effective surveying, modeling as well as maintenance of the water distribution network system.

\section{Acknowledgement}

The authors wish to thank The Principal, PSG College of Technology for the encouragement. Thanks are due to Professor and Head of the Department of Civil Engineering, PSG College of Technology for the facility provided.

\section{References}

[1] Arunkumar.M\&NethajiMariappan V.E (2011),"Water demand analysis of Municipal Water Supply using EPANET software"International Journal on Applied Bioengineering, volume-5, Pages 9-19

[2] BUREAU OF INDIAN STANDARDS -CRITERIA FOR DESIGN OF RCC STAGING FOR OVERHEAD WATER TANKS (First Revision of IS 11682) Doc: CED38 (7811)P June 2011.

[3] Darshan Mehta, Krunal Lakhani, Divy Patel \&Govind Patel, "Study of Water Distribution Network using EPANET", International journal of advanced research in engineering, science \&management. 
[4] IS 11682 (1985): Criteria for design of RCC staging for overhead water tanks. [CED 38: Special Structures]

[5] IS 1172-1993 Code of Basic Requirements for Water Supply, Drainage and Sanitation.

[6] Lewis A. Rossman (September 2000) EPANET 2 USERS MANUAL- Water Supply and Water Resources Division National Risk Management Research Laboratory Cincinnati, OH $45268 \mathrm{EPA} / 600 / \mathrm{R}-00 / 057$.

[7] M. Tholkapiyan, A.Mohan, Vijayan.D.S , "A survey of recent studieson chlorophyll variation in Indian coastal waters", IOP Conf. Series: Materials Science and Engineering 993 (2020) 012041, doi:10.1088/1757-899X/993/1/012041.

[8] Nitin P. Sonaje\&Mandar G. Joshi,(2015)“A REVIEW OF MODELING AND APPLICATION OF WATER DISTRIBUTION NETWORKS (WDN) SOFTWARES” International Journal of Technical Research and Applications, volume-3, Pages 174-178.

[9] Ramesh.H, Santhosh.L, Jagadeesh.C.J.(2012), "Simulation of Hydraulic Parameters in Water Distribution Network using EPANET and GIS", international conference on ecological, environmental and biological sciences, Pages 350-353

[10] RsooliAhmadullah\& Kang Dongshik(2015)"Designing of Hydraulically Balanced Water Distribution Network Based on GIS and EPANET", International Journal Of Advanced Computer Science And Applications, volume-7, Pages 118-125.

[11] Santhosh Kumar Garg "Water Supply Engineering" Khanna publishers (2012) Pages 8$13,22,23,579-605,616-622$

[12] Shamsi.U.M "GIS application for Water, Wastewater and Stormwater Systems" CRC Press (2005).

[13] S. M. S. S, D. S. Vijayan, M. Anand, M. Ajona, and T. Jarin, “ Biodegradation of P-nitro phenol using a novel bacterium Achromobacterdenitrifacians isolated from industrial effluent water," Water Sci. Technol., vol. 00, no. 0, pp. 1-12, 2021, doi: 10.2166/wst.2021.354

[14] Vipinkumar G Yadav, Darshan Mehta \&Sahita I Waikhom,(2015)“To assess the prevailing Water Distribution Network using EPANET", International Research Journal of Engineering and Technoloy, Volume-02, Pages 777-781.

[15] Yuvaraj .D , Alaguraja .P, Sekar.M, Muthuveerran.P,Manivel .M, (2010), “Analysis of drinking water problem in Coimbatore City Corporation,Tamilnadu, India using Remote Sensing and GIS tools", Volume-1, Pages 71-76.

[16] http://www.esri.com/library/whitepapers/pdfs/implementing-arcgis-for-water-utilities.pdf accessed on 26/12/2016

[17] http://www.epa.gov/ordntrnt/ORD/NRMRL/wswrd/epanet.html -accessed on 16/01/2017

[18] http://pbadupws.nrc.gov/docs/ML0825/ML082590504.pdf -accessed on:02/02/2017

[19] http://sdteffen.de/diplom/web/node11_mn.html -accessed on 03/03/2017 